IJIET, e-ISSN 2548-8430, p-ISSN 2548-8422, Vol. 2, No. 2, July 2018

\title{
IJIET
}

International Journal of Indonesian Education and Teaching http://e-journal.usd.ac.id/index.php/IJIET

Sanata Dharma University, Yogyakarta, Indonesia

\section{NURSING STUDENT'S EXPERIENCE IN CARING CHILDREN WITH DISABILITY: A QUALITATIVE STUDY}

\author{
Erna Erawati and Budi Anna Keliat \\ Poltekkes Kemenkes Semarang and Universitas Indonesia \\ ernaerawati57@yahoo.com and budianna_keliat@yahoo.com \\ https://doi.org/10.24071/ijiet.v2i2.1262 \\ Received 2 May 2018; revised 12 June 2018; accepted 3 July 2018
}

\begin{abstract}
Caring children with intellectual disability remains a challenge for nursing students due to unprepared feeling and lack of experience. Therefore it is important for the nursing students to increase their self-awareness in caring children with intellectual disability through their clinical placement. The aims of this study are to explore the experience of the nursing students caring children with intellectual disability. A qualitative approach using a phenomenological was applied to explore the experience of the nursing students in caring children with intellectual disability. One time semi-structured interviewed were conducted. Datawere collected through personal interviews about their experience and the transcripts of these interviews were subjected categorically. Data analysis identified the emerging themes as changing perception, communication challenges, and life value in caring children with intellectual disability. Findings suggest strategies to promote competencies of the nursing students in caringchildren with intellectual disability.
\end{abstract}

Keywords: intellectual disability, nursing students, qualitative research

\section{Introduction}

Intellectual disability is neuro-developmental disorder classified as mild, moderate, severe and profound mental retardation according to ICD-10(1) (1) (WHO, 2010). Smiley (2007) mentioned that the incidence of people with intellectual disability as much as $2 \%$ of the population. The prevalence of children of 24-59 months with disability in Indonesia based on Riskesdas 2013 was 0,53\% (Kemenkes, 2014). Furthermore, this information help to design the effective intervention for children with disability, so that they have the same chance to reach optimal function in their life (Isfandari, 2009). RCN (2017) mentioned that children with a mild intellectual disability may only need support in understanding health information, accessing health screening program or managing any complex health care, but children with a profound intellectual disability may need full-time support.

Children with intellectual disability have right to be educated in the school and accessed health care appropriately to prevent discrimination and inequality. It is a challenge for nursing education to prepare their student to have competency in 
providing direct care for children with intellectual disability because they have a lifelong condition with difficulty in everyday tasks. Nursing students need to know how to caring children with intellectual disability to increase their competence. However, there is a lack of research that addresses the experience of nursing student caring children with disability. There is no discrimination in accessing health service and education wherever appropriate, especially in the school. School nurses play an important role in giving care to the same levels of service as other children. By directing their contact with complex of children with an intellectual disability, the nursing student gets experience in their clinicalpractice in a special school.

Working with children with disability remains a challenge for nursing students due to unprepared feeling and difficulty to communicated effectively (Singer, 2012). This accordance with Fisher, Frazer, Hasson, and Orkin (2007) found that lack of education in disability studies and a lack of experience may impend nurse to provide health care for children with intellectual disability. The aims of this study are to explore the experience of the nursing student working with children with intellectual disability. The research question was explored during this qualitative study what is the experience of nursing students in caring children with an intellectual disability?

\section{Method}

\section{Study design}

A qualitative study using a phenomenological was applied to explore the experience of the nursing student in caring children with intellectual disability. Data were collected using one time semi-structured interviewed through personal interviews about their experience in caring children with intellectual disability.

\section{Participants}

There were a total of 40 nursing students who take a clinical placement in caring children with disability, however; only 7 of the 40 nursing students have willing to participate in this study. The purposive sampling was chosen in this study in order to elicit the true experience of the nursing students in caring children with disability. Most of the participants were females and only one of them was male. All of them were 22 years old and in third grade of applied nursing study program Magelang, Poltekkes Kemenkes Semarang, Indonesia.

\section{Ethical consideration}

Institutional Review Board permission was obtained from Poltekkes Kemenkes Semarang that the researcher attended as well as the study school district. The nursing students signed informed consent prior to the study. All of the research materials were handled exclusively by the researcher and no student names were associated with any final written materials.

\section{Data collection}

The study was conducted in a public school setting in the special school, Balai Besar Rehabilitasi Sosial Bina Grahita (BBRSBG), Temanggung, Central Java. The nursing students were arranged for a 3-week clinical placement in BBRSBG, after finished their study for disability module in one semester in nursing program study, BBRSBG is a school for children with special needs 
facilitates nursing students to practice nursing clinical placement as their new learning experience. This condition provides valuable learning opportunities for nursing students develop their communication skill in caring children with intellectual disability (Southgate, 2012). They learn to apply communication technique and nursing management in caring children with learning disability in school settings. Semi-structured interview was done at a mutually agreed upon time and place. After the interview was completed, data collection was done to gather the nursing student's experience in caring children with disability.

\section{Data analysis}

Once data were collected, a categorical analysis was used to analyze data and findings were reported using a narrative format. Data were analyzed using categorical analysis and transcribed after the interview occurred. The transcripts of these interviews were subjected categorically. Data were coded according to common experience. After that data were categorized into themes and interpreted to answer the research question. The final data were cross-checked among the researcher and with the participants to ensure the credibility of the research.

\section{Findings and Discussion}

Seven nursing students who underwent clinical placement in the special school participated in this study (see table 1).

Table 1. The sociodemographic characteristics of nursing students

\begin{tabular}{llll}
\hline $\begin{array}{l}\text { Participants } \\
\text { Pseudonym }\end{array}$ & Age & Sex & Grade \\
\hline Hanna & 22 years old & Female & Third grade \\
Emma & 22 years old & Female & Third grade \\
Lisa & 22 years old & Female & Third grade \\
Vanny & 22 years old & Female & Third grade \\
Elly & 22 years old & Female & Third grade \\
Sally & 22 years old & Female & Third grade \\
Garreth & 22 years old & Male & Third grade \\
\hline
\end{tabular}

The interactive experiences nursing students with children with intellectual disability give the students the opportunity to learn for the first time and practice the role as a caregiver. The nursing student demonstrated 3 common themes in caring children with intellectual disability. All of the details are as discussed below. A summary of the themes is shown in figure 1 .

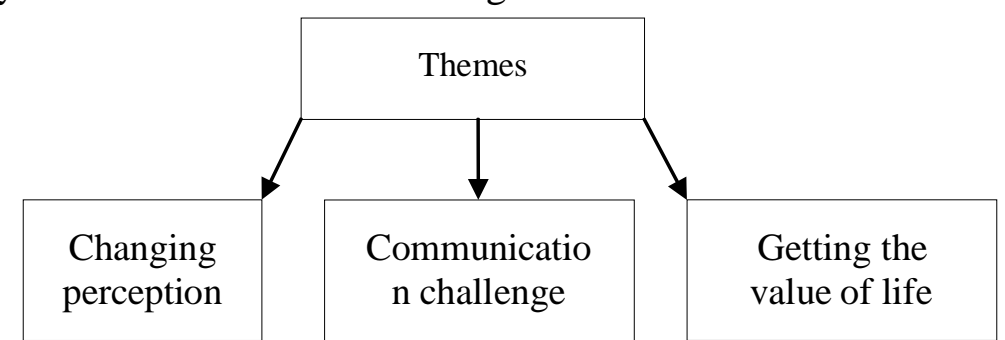

Figure. 1. Themes identified through analysis of caring children with intellectual disability during clinical placement. 


\section{Changing perceptions}

The nursing students were encouraged to identify their perception of children with intellectual disability. Most of the nursing students avow stigmatization and marginalization of children with intellectual disability, but their perception was changed after they had interaction with.

"I have expressed pessimistic with the label of intellectual disability, but when the first time I met them in the special school, they have shown hospitality more than usual kids. They behave politely, although some of them less cooperative. This occurs as a result of difficulty to participate in theactivity." (Hanna).

"I have thought that they prone to be lazy, but after we gave direction to simple instruction, they have a passion to follow it." (Garreth).

"First time I met in the class, the children easily directed and manageable, it differs with my perception about their challenging behavior because of their disability. Now I have a better understanding of them." (Sally).

"For the first time, I was surprised how they were so excited about our coming as if they have a new friend. That really changed my perception and itwas really awesome to feel that way." (Vanny).

"Now I would not stigmatize disability for did not have an ability, they were unique and special children who need caring." (Emma).

\section{Communication challenge}

Practicing effective communication is a challenge for nursing student dealing with different characteristics of children with intellectual disability. Collaboration with other healthcare member is another communication challenge in caring children with intellectual disability. Thus, the nursing student in this study applied their communication skills and learned to sharpen it during administering nursing care. The opinions of nursing students collectively support communication challenge, as demonstrated below:

"Some children have unique ways of communication, some of them speaks fluently, but did not reach to the specific topic. In dealing with profound intellectual disability, patience was needed." (Lisa)

"I learned to approach children in a proper way so that he/she can understand me and follow my simple instructions." (Elly)

"They wanted to be heard. What they said to be heard well. I learned about their gesture, and using nonverbal communication is a challenge for me.(Sally). 
They become more sensitive if I did not sincere and genuine in what I say they can feel it. If they did not feel comfortable, they did not want to listen to us. (Vanny)

"The special school gives us a chance for giving intervention in the class, and we also learn how to communicate in collaboration with psychiatrist and psychologist in caring children with intellectual disability." (Garreth).

\section{Getting the value of life}

The findings demonstrated that nursing students learned the value of life during their experience. The value of life as displayed below:

"I started to realize you know how the children are going through and struggle with their life. I get connected with the children and realize the bigger picture. Sincerity is the important things in caring children with disability.” (Hanna)

"I am so fortunate and I cannot even begin to describe how grateful I am for a chance to have gone through my experience. They give me spirit I learned to be tough and fortitude. Sometimes I catch myself looking down onchildren for their issues."(Emma)

"I am taught a certain thing from them. They were always excited despite their condition and they learned to respect each other. They interact lovingly and caringly." (Lisa)

All the participants were considered in the results and the data were included in the analysis. There was no issue of a difference of opinion between the 2 researchers during the process of theme extraction. This study explored the experience of nursing students in caring children with intellectual disability. The analysis of data provides information on the summary of the experience while caring children with intellectual disability from the clinical placement. Among the participants in this study, the nursing student's experience was explored as providing an information about changing their perception. The results demonstrated the process of changing perception from stigmatization into understanding the characteristic of children with intellectual disability. Nursing students needed to understand the task and make them understood the instruction. They need more time to think and grab relevant information from memory, so they could communicate their thoughts and feelings (WWILD, 2012). The results of the current study supported the fact that the students benefitted from the interaction. Antonsson et al. (2008) mentioned that if the interactions success, it to positive influences but if it is not, the interaction would lead to irritation, aggression, and violence among services user.

The children with intellectual disability usually have unique communication and unclear conversation. Emerson (2001) found that $60 \%$ of people with intellectual disabilities commonly used symbolic communication through pictures, symbols, signs or speech to communicate. The difficulty in communication associated with intellectual disability can be a barrier for children to express their 
needs. Emerson (2001) found that $60 \%$ of people with intellectual disabilities commonly used symbolic communication through pictures, symbols, signs or speech to communicate. The difficulty in communication associated with intellectual disability can be a barrier for children to express their needs. Therefore it is important for the nursing student to be aware of the communicationneeds of children with intellectual disability to enable effective communication (RCN, 2017).

Nursing students have the challenge to differentiate when using pre-symbolic, symbolic and verbal communication to children according to their ability in understanding (Baron, 2009). A combination of both verbal and non-verbal strategies should be considered by nursing students. Sherko, Sotiri, and Lika (2013) mentioned that the nurse could use the communication technique such as active listening, sharing observations, sharing empathy. Chew, Iacono, and Tracy (2009) identified the way children with intellectual ability expressed their wants, needs or feelings such as speech, augmentative visual or behavioral cues. Martin, Fenelon, Lyons (2010) also mentioned that care, creativity, and innovation are required in communicated with children with intellectual ability.

\section{Conclusion}

From the result of the study, the nursing students also got life value in caring children with intellectual disability. They expressed their feeling which has demonstrated that children have a high sensitivity, so the nursing student learned to be patient. Nursing students had undergone a process of self-evaluation during the experiences. They mentioned sincerity, toughness, fortitude, respect, and love. While recognizing their stigmatization, nursing students showed their passion to give nursing care with plans and suggestions. This is accordance with the research of Cooper et al. that found that their students reflected both positive and negative characteristics in themselves while dealing with different patients.

The main weakness of the qualitative study is that it is not possible to make quantitative predictions. However, the strength of this research is that this study provides an understanding of nursing students' experiences in caring children with intellectual disability. In conclusion, the nursing students were being encouraged to be aware of their self-process in caring and develop their sensitivity and a new sight in caring children with intellectual disability.

\section{References}

Antonsson, H., Granheim, U.H., Lundström, M. \& Åströ S. (2008). Caregivers' reflections on their interactions with adult people with learning disabilities. Journal of Psychiatric and Mental Health Nursing, 15(6), 484-91.

Chew, K. L., Iacono, T., \& Tracy, J. (2009). Overcoming communication barriers: Working with patients with intellectual disabilities. Australian family physician, 38(1/2), 10.

Emerson, E., Hatton. C., \& Felce, D. (2001). Learning disabilities: The fundamental facts. Foundation for People with Learning Disabilities.

Fisher, K., Frazer, C., Hasson, C., \& Orkin, F. (2007). A qualitative study of emergency nurses' perceptions and experience in caring for individuals with 
intellectual disabilities in the United States. International Journal of Nursing in Intellectual and Developmental Disabilities, 3. Retrieved from http://journal.hsmc.org/ijnidd/print.asp?id $1 / 4127$

Isfandari, S. (2009). Manfaat data disabilitas Riskesdas bagi perencanaankesehatan di Indonesia. Buletin Penelitian Sistem Kesehatan, 12(3).

Kemenkes. (2014). Situasi penyandang disabilitas. Buletin Jendela Data dan Informasi Kesehatan, 2(11).

Martin, A.M., Fenelon, M.C., \& Lyons, R. (2010). Non-verbal communication between nurses and people with an intellectual disability: a review of the literature Journal of Intellectual Disabilities, 14(4), 303-314. DOI: $10.1177 / 1744629510393180$

Royal College of Nursing (RCN). (2017).The needs of people with learning disabilities: what pre-registration students should know. ISBN: 978-1910672-82-2. Retrieved from www.rcn.org.uk.

Sherko, E., Sotiri, E., \& Lika, E. (2009). Therapeutic communication: a review article. JaHR, 4(7), 457-466.

Singer, B. (2012). Perceptions of school nurses in the care of students with disabilities. The Journal of School Nursing, 29(5), 329-336. DOI: 10.1177/1059840512462402. Retrieved from jsn.sagepub.com.

Smiley, E., Cooper, S. A., Finlayson, J., Jackson, A., Allan, L., Mantry, D., \& Morrison, J. (2007). Incidence and predictors of mental ill-health in adults with intellectual disabilities: prospective study. The British Journal of Psychiatry, 191(4), 313-319.

Southgate, A. (2013). Critical reflection on practice development. Confounding expectations: Reflection on simulation with learning disability service users. FoNS. International Practice Development Journal, 3(1), 8. Retrieved from http://www.fons.org/library/journal.aspx.

World Health Organization. International Statistical Classification of Diseases and Related Health Problems 10th Revision (ICD-10) Version for 2010. WHO. 